\title{
Modular Manufacturing Experience in the South African Clothing Industry: Lessons Learned
}

\author{
Kem Ramdass ${ }^{1,}$ Leon Pretorius ${ }^{2}$ \\ ${ }^{1}$ Faculty of Arts, Design and Architecture, University of Johannesburg, South Africa \\ ${ }^{2}$ Graduate School of Technology Management, University of Pretoria, South Africa
}

\begin{abstract}
The global economy which is enhanced through changing technologies is pressurizing organisations to improve productivity of their business processes. Competition is forcing organisations to focus their energy on core competencies. Like many industries, the clothing industry is witnessing changes in technology, diversification of labour, managerial implications while competing on the global market. The South African clothing and textile industry has the potential to create jobs, but this potential has been steadily diminishing. The performance of the clothing industry, whether in terms of efficiency, working conditions or degree of social protection, is unstable. The industry's ability to generate sustainable and productive employment varies according to geographical locations. The process improvement methodology that could improve the status quo in the clothing industry is modular manufacturing, which is the focus of this paper. Qualitative results of the implementation of modular manufacturing and its relative experiences at a South African clothing manufacturer are presented through a case history.
\end{abstract}

\section{INTRODUCTION AND RESEARCH METHODOLOGY}

The SA clothing industry shed over 67000 jobs in the past three years [3].There is a possibility that more jobs may be shed in Durban (Kwa-Zulu Natal). The Alexander Report mentions that between July 2006 and May 2007 there was a drop of 5275 in employment figures [17]. The cut, make and trim (CMT) industries find it difficult to negotiate wage increases as production costs escalate beyond proportion. If the lay off of workers continues in the clothing industry, it would increase the unemployment rate, thus impacting on the economy.

The growth, employment, and redistribution (Gear) document predicted that, the researcher quotes: "As South Africa proceeds with trade liberalisation and adapts to international competition, downward pressure will be placed on unskilled wages. If this is not accommodated by the labour market, then unemployment will rise and irregular, insecure forms of employment will increase" [10].

Thus, as one observes the trends in the clothing and textile industry, there is evidence that the above prediction is becoming a reality. Chinese goods are flooding the South African market, not only clothing and textiles, but also electrical and electronic goods, motor vehicles and many other products [13]. Chinese imports are having a major impact on employment all around the world, and South Africa is no exception [8]. Approximately 30-million jobs worldwide are at risk and the world unemployment rate
(January 2006) stands at $6.3 \%$, approximately 191.8 million [27].

Manufacturers that find it impossible to compete on garment price move their production facilities to nonmetropolitan areas in South Africa while others move out of SA. The justification for relocation primarily centred on labour costs. Clothing manufacturers relocated to areas such as Qwa-Qwa, Isithebe, Lesotho and Swaziland to name but a few locations. The enforcement of labour rates by the bargaining council cause manufacturers to either relocate, operate as an unregistered organisation or shut down their plants as they fail to comply with bargaining council requirements [15].

The South African clothing and textile union (SACTWU) argue that the rate of pay of South African machinists is low. The trade unionists are concerned that with the diminishing workforce in the clothing industry, their bargaining powers are being eroded. Unions are retaliating as their membership numbers are declining. With the wage structure impacting on the organisations' success, manufacturers negotiate plantlevel agreements to remain outside the scope of the bargaining council [16].

China is strategizing in capturing a bigger share of world markets. The Chinese clothing and textile industry has approximately 15 million workers and 300,000 factories. The lifting of the trade quotas on January 1, 2005 by the world trade organisation promoted the influx of imported goods into South Africa. This means low cost garments for the global consumer but on the other hand pain and suffering as millions of jobs are lost worldwide[18].

China's foreign trade volume passed the $\$ 1$ trillion mark, making it the world's third largest trading power as reported by the official Xinhua news agency. The World Trade Organisation (WTO) estimates through a forecasting model that China's share of the world market could rise up to 50 percent by 2010 . It was projected by a Hong Kong-based executive that $70 \%$ of clothing and textile in the world could eventually be produced in China [18].

The research methodology employed in this paper is qualitative and exploratory in nature making use of applicable literature and the application of action research to highlight the experiences during the implementation of modular manufacturing [6]. The research highlights some of the issues affecting the SA clothing industry and includes a review of secondary data including existing literature and documents on the industry from Clofed, Texfed, relevant research reports from the DTI and NEPAD in South Africa, as well as relevant journal articles such as in the International Journal 


\section{PICMET 2009 Proceedings, August 2-6, Portland, Oregon USA (C) 2009 PICMET}

of Clothing Science and Technology and Operations Management. Qualitative results of a case history using the implementation of modular manufacturing are presented and compared with some results from literature.

\section{LITERATURE REVIEW}

The multitude of competitive priorities has been the subject of considerable argument by manufacturers around the world. A universal set of priorities does not exist for all the firms in the global marketplace. The competitive priorities that organisations focus on can be categorized into price; flexibility; quality and dependability. Ward et al [22] identified five different dimensions namely price; quality; dependability; product flexibility; and volume flexibility.

Chan et al [5] proposed a combined list of competitive priorities, including plant and equipment, production planning and control, labour and staffing, product design and engineering, and organisation and management.

Hill [12] argued that a firm should identify those criteria or priorities that win orders against the competition in the marketplace. His "order-winning" criteria included price, delivery, quality, product design and variety. Hill also considered that "qualifying" criteria (or performance criteria) were also important for an organisation.

Krajewski and Ritzman [14] put forth a more detailed list by differentiating four different aspects namely, cost; quality; time; and flexibility.

In the South African clothing industry context, competitive strategies that require implementation as a matter of urgency from the researcher's perspective would be leadership that is people orientated with an insight into cultural diversity, financial management by understanding organisational costs, service delivery with quality management imperatives and last but not least, performance management initiatives.

\section{TRENDS IN THE CLOTHING AND TEXTILE INDUSTRY IN SOUTH AFRICA}

The clothing and textile industry seems to be on a downward spiral since trade liberalisation. Some of the relevant issues are discussed in the following subsections.

\section{A. Declining value}

Barnes, et al [1] mentioned that the clothing sector performed poorly. The researcher quotes from Barnes, "By comparing the average of the indicators for the period 1994-8 with the average for the period 1999-2003, it was clear that the sector's performance deteriorated. In particular, there was deterioration in real value added at basic prices $(10.4 \%)$, realexports $(4.4 \%)$, employment $(0.6 \%)$, output per employee $(11.9 \%)$, remuneration per employee $(6.8 \%)$ and gross markup $(7.8 \%)$. Interestingly, both exports and employment increased (by $1.8 \%$ and $1.1 \%$ per annum respectively) from 1994 to 1998 , but declined (by 8.0\% and 1.1\%) from 1999 to 2003, while real value added declined consistently over the two periods. Real output per employee declined from R67,935 to R60,716 between the two periods, whilst remuneration per employee also fell (from R18,935 to R17,224)."

\section{B. Employment trends}

Employment in the clothing and textile industry is unsteady. It fell by $18.8 \%$, from 124687 employees in 1993 to 101234 by Sept 2004 - a loss of 23453 jobs. It is important to note that official statistics is likely to underestimate total clothing industry employment as informal, micro and home industries tend to be excluded. It was estimated that total clothing and textile employment to be 158,879 by end 2005 [1].

Employees of the clothing and textile industry experience problems in finding suitable employment. Some of these employees formed closed corporations and excelled in their ventures.

TABLE1. EMPLOYMENT TRENDS IN THE SA CLOTHING AND TEXTILE INDUSTRY $[24$
\begin{tabular}{|c|c|c|c|c|}
\hline & $\begin{array}{c}\text { Spinning, } \\
\text { weaving \& } \\
\text { finishing }\end{array}$ & $\begin{array}{c}\text { Other } \\
\text { textiles }\end{array}$ & $\begin{array}{c}\text { Knitted/croche } \\
\text { ted fabrics \& } \\
\text { articles }\end{array}$ & Clothing \\
\hline 1993 & 35260 & 30695 & 15976 & 124687 \\
\hline 1994 & 35839 & 32053 & 14567 & 124538 \\
\hline 1995 & 34641 & 32369 & 13682 & 134945 \\
\hline 1996 & 45566 & 32886 & 19158 & 149219 \\
\hline 1997 & 42744 & 32713 & 18484 & 136433 \\
\hline 1998 & 30169 & 26725 & 14540 & 113577 \\
\hline 1999 & 26278 & 27719 & 11661 & 122380 \\
\hline 2000 & 25379 & 30097 & 11150 & 125237 \\
\hline 2001 & 25203 & 28169 & 10701 & 122513 \\
\hline 2002 & 26634 & 27904 & 10913 & 122531 \\
\hline 2003 & 23029 & 34765 & 12675 & 103935 \\
\hline $09 / 2004$ & 19954 & 31516 & 10107 & 101234 \\
\hline
\end{tabular}




\section{PICMET 2009 Proceedings, August 2-6, Portland, Oregon USA (C) 2009 PICMET}

\section{Closures of clothing organisations}

Clothing and textile organisations in South Africa that are unable to cope with the changes in industry sought closure as a resolution. According to the Inggs [13] approximately thirty clothing and textiles companies closed since July 2002. Many of these organisations sought legal advice on the process of liquidation. Closures are wide ranging, from textile manufacturers that produce standardised products to clothing manufacturers who focus on the fashion trends of the industry. Chinese imports proved to be intimidating force for the entire clothing value chain.

Organisations that are involved with standard products found the competition stifling. These organisations (especially textiles) are pressured to shut certain parts of the operations only. A very good example is Coats South Africa that closed its spinning and twisting departments. It imports yarn ready for the dyeing process from sister companies around the world. Such organisations streamlined the production process to focus on specialised products [1].

\section{South African organizations foreign take-over}

Trade liberalisation prompted organisations to focus on its competitive abilities. In this regard an investment in the latest technology and human assets is required. Foreign investment is imperative to bolster the industry in its pursuit of becoming competitive. The latest example is Edcon, which was taken over by the Anglo-American group in April 2007. Approximately 30 percent of the clothing and textile firms in SA are under foreign ownership as organisations strained under competitive pressure [1].

\section{E. Relocations of South African organisations}

Many clothing and textile firms, South African clothing industries (SACI) as an example, relocated to industrial districts such as Isithebe, Madadeni and Ladysmith. The organisations in urban areas are required to comply with the Bargaining Council regulations and unionised labour, thus escalating the cost of production. Rural areas constituted discretionary wage rates as determined by the employer and minimal union interference. The union has an important role to play in the South African clothing industry but stakeholders need to apply themselves in a harmonious relationship [20].

Many clothing and textile manufacturers abandoned their South African operations to set up facilities in neighbouring countries such as Lesotho, Swaziland and Botswana. The Botswana government provides incentives for clothing and textile manufacturers to invest in the country. In addition to this, there is skilled labour at approximately half the price of SA. These manufacturers are allowed to import raw materials according to the AGOA agreement [1].

\section{F. Performance of the industry}

The clothing industry in SA is performing in the region of $85 \%$ labour efficiency. Capital expenditure on new assets averaged approximately $1.4 \%$ of sales (Robbins, 2004). With clothing manufacture being labour intensive it is important to advance through the investment in capital requirement and technological innovations to overcome the competitive nature of the industry. Exports decreased, while imports increased. Labour efficiency of the SA clothing operators is approximately on par with the United Kingdom, European Union and the United States but it is the application of technology, working culture and productivity levels that are a matter of concern [2].

\section{G. Multilateral agreements}

Multi-Fibre Agreement (MFA): The MFA came to an end on December 31, 2004. This meant the termination of all quotas on textiles and clothing trade between WTO member states. This is having an impact on clothing and textile industries around the world. China is using this as a weapon to flood the clothing and textile markets. In a quota-free world, experts in clothing and textiles envisage that China's dominance on world markets would continue at an alarming rate, and double its exports over the next five years [11].

China and India are expected to dominate global production, with preliminary evidence from early 2005 . India's overall clothing and textiles exports increased $33 \%$ in January 2005, when compared against January 2004 figures. China experienced an even more astounding 546\% increase [22].

\section{IMPLEMENTING MODULAR MANUFACTURING}

As a precursor to a discussions of the results and experiences of introducing modular manufacturing at a case study South African clothing manufacturer some pertinent context of modular manufacturing is provided using appropriate literature and some practical experience of the authors. Thereafter the results of the introduction of modular manufacturing in the South case study and lessons learnt will be communicated using qualitative techniques and verbal qualitative summaries of interviews conducted onsite.

\section{A. Concept of modular manufacturing}

Modular manufacturing was the "buzzword" during the early 2000's and the latest technology that could improve performance in the clothing industry, especially for short production runs of fashion items. Another aspect of the methodology is that operators could sit/stand during the sewing operation, thereby enhancing teamwork, quality and output. It is based on self- managed teams in the production of garments. Production is organised in a synchronized manner that eases the flow of production through the various processes. To accomplish efficient performance, standard times are determined using work-study principles for all operations. Workloads are distributed such that each activity has an approximate equal amount of work to balance the line of production efficiently.

The most important aspect of modular manufacturing is team members' culture and attitude, with a high focus of 


\section{PICMET 2009 Proceedings, August 2-6, Portland, Oregon USA (C) 2009 PICMET}

understanding of improvement techniques applied in the industry. This allows operators to work as a "family" to attain high performance and productivity levels.

The concept requires the commitment of top management and an understanding of the dynamics of the concept. Without an understanding, the project could lead to failure. Finally, the choice of participants is a critical factor that would determine the success or failure of the operation. It is advisable to start such a process with in-depth planning and a trial run to determine the strengths and weaknesses of modular manufacturing. This chapter examines the prerequisites for the implementation of successful modular manufacturing and discusses, through a case study methodology, the experiences of employees in the various stages of modular manufacturing implementation. The concepts of team-working, cellular/modular manufacturing are used interchangeably.

\section{B. Prerequisites for modular manufacturing}

The planning stage of modular manufacturing is of utmost importance as it is a dynamic change from the normal line operation. The planning should be done in stages so that information is gathered on the feasibility of the change.

- Stage 1 Business planning

- Questions asked when planning the change to modular manufacturing are listed as follows:

- What are the goals of the organisation? - to produce quality clothing at a low price.

- Where are we now and where do we want to be? currently struggling to survive but we want to strive to be the best producer of fashion wear.

○ What are the reasons of going modular? - improve quality, efficiency and meet customer deadlines.

- Stage 2 Project planning

○ Set up project team

- Initial project team (management) training

- Stage 3 Develop plans

- Layout and size of teams? Sitting or standing? How to cover for absence?

$\circ$ Levels of WIP? Single piece VS bundle? Size of bundle?

○ Machinery? Special Machines? Spare machines? How to handle repairs? Role of mechanics?

○ Suppliers (all trims)? Can they meet tighter schedules?

- Production control? What changes to your system are required? Will production control staff require training?

○ Payment system? Individual or group incentive, or flat rate? What about indirect labour?

○ Pay for 1st quality only? Pay for meetings? Training and multi-skilling?

o Selecting the team? Volunteers, grouping by efficiency/skill level? Ethnic mix? How to handle operatives with high earnings? Pay during start up?
- How to handle people who want to leave the group? How to handle people when the team/management wants them out of the group?

- How much multi-skilling?

○ What, if any provision for part-timers?

○ Supervision? Selection, responsibilities.

- Stage 4 Training needs analysis (develop a training plan)

- Managerial and supervisory training

- Operative training - team-working, technical training, multi-skilling, (Who does the training - in-house or outside specialists? Do team members teach other team members?)

- Stage 5 Communication

- Discuss objectives and plans with union and employees (large or small meetings)

- Stage 6 Develop pilot team(s)

- One group or two (to compete with each other)

- How are they selected?

- Training, development and coaching

- Stage 7 Review

$\circ$ What have we learned from the pilots? What should we keep? What should we change?

- Strategy for further groups? Timetable?

- Stage 8 Develop further teams

○ Review continuously? Be flexible.

\section{Recruitment of team members}

The recruitment of team members is a crucial stage in the development of a module. Members of the team are generally recruited within the organisation from areas such as the training school or from within the production line. Management needs to select members of the team that work effectively together. In general this sort of recruitment is regarded as desirable once a modular system is firmly established.

\section{How much participation should be permitted?}

In modular manufacturing, teams are generally self directed and have a degree of autonomy [4]. For example, when a new style is introduced the company would provide the operations in sequence, but if the team suggests a better way of constructing the garment, they are allowed to put their ideas into practice. Where suggestions are made and implemented, it enables people to take ownership and pride in their work.

\section{Planning for modular manufacturing}

Successful implementation demands careful planning. The 8-stage plan would provide a guideline for organisations considering modular manufacturing. 


\section{PICMET 2009 Proceedings, August 2-6, Portland, Oregon USA (c) 2009 PICMET}

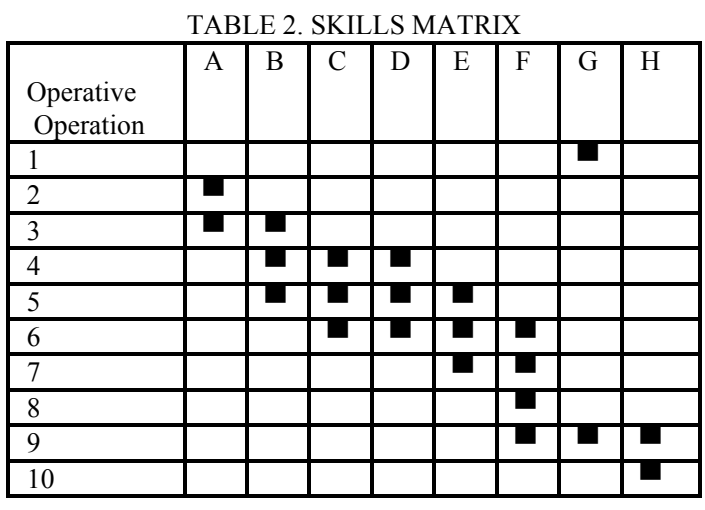

The matrix provided a guide as to the allocation of tasks to the various operators and help to provide a balance in the content of the tasks allocated. The operations are listed horizontally and allocated to operators vertically. As an example, operator A would perform operation 2 and 3 . This is where multi-skilling is important as operators need to be versatile in any operation on a garment.

\section{Plant history and context of the case history}

The production facility used in this case history manufactured men's and ladies fashion wear and operates in a small town in Kwa-Zulu Natal. The factory opened in 1970 with approximately 300 people and implemented modern technology. The facility had 16 supervisors and a plant manager.

The plant manager agreed to perform a pilot project on team-based manufacturing as orders of 100 units were received. The sewing department has since reverted to the bundle system due to larger orders. Due to the inconsistency in the order sizes the organisation abandoned the Eton system (overhead rail system) and reverted to the bundle system of manufacture.

The plant followed conventional management practices before the 1980's but started changing as new management came on board. There was very little interaction among employees and management and there was an autocratic style of management.

Before the year 2000 the production facility was accustomed to lot sizes of between 2000 and 10000 units per order. Currently, there are lot sizes of approximately 100 units per order. The garments were not as complex in construction as the ones received currently. The factory was "flooded" with high lots of work-in-process throughout the plant. Employees who were loyal and employed for the last 30 years said that the environment in which they worked was hostile and they did the same operation for several years.

\section{Results and discussion}

This section contains a qualitative discussion lessons learnt and of the experiences of the people involved in the implementation of modular manufacturing case study done as part of the research. They felt that management commitment and education/training is the most important aspect of any initiative in an organisation.

\section{Management commitment}

Any change in the organisation stems from top management. Commitment from management drives the process of change and nothing can be achieved if management does not support the initiative. Once management gives their approval any change is possible, but employees need to understand and support the changes for it to be successful.

Management realised that in order to counteract the threat of imports they would try out the team-working concept although employees wished for "the good old days." They could not afford huge piles of inventory on the machine floor.

Employees were delighted that the plant manager supported the initiative and frequently visited to find out how they were performing. An employee of the team briefly summarized how he felt.

Any project has to have the "blessings" of management and the acceptance from employees for it to be successful. The managing director of the organisation initiated the process of change as funding in terms of labour is involved. Support from management, especially in terms of funding is important for a project of this nature.

The planning, organising, leading and controlling of the project are important as it would benefit the organisation over a period of time. The clothing industry is in need of radical change that would be able to counteract the competition faced. Employees were thankful that they had commitment and the necessary expertise from the management team.

\section{Education and training}

A number of training sessions were held with the team of employees to provide orientation with the objectives of the project. Employees held discussions regarding their concerns so that everybody understood their role in the project. The researcher explained that this was a pilot project for the purpose of adding value to the organisation and if it did not work, they would go back to the assembly line system using the bundle system methodology.

The organisation invested in training and development of employees on an ongoing basis. It was mentioned that training of employees in the latest developments would enhance employee skills and workers would embrace changes in future. Another employee's experiences was that people would be willing to change if they knew what the change was all about and how it would impact on their work. Mention was made that employee involvement from the very outset would clear any negativity that may be spread through the grapevine within the organisation. It was said that management discussions behind closed doors regarding changes are unhealthy for an organisation. Open communication and the building of trust among the people are extremely important. 


\section{PICMET 2009 Proceedings, August 2-6, Portland, Oregon USA (C) 2009 PICMET}

An employee mentioned that learning can only take place by change in attitude and behaviour. She also mentioned that training makes employees aware of what is happening and what to expect and it removes barriers between people and is also a great motivator for the workforce.

Employees were enlightened on the benefits of team-work and how it could change the entire organisation. An employee mentioned that training made them understand the current status in the clothing industry and how they could rise above the competition. It was mentioned that they are setting an example for the industry to follow and they could be the best manufacturer in the clothing industry. The advantages they experienced created team-spirit and they found that they were responsible for the making this project a success.

Another employee mentioned that the concept would be ineffective and that government intervention was the only way that the industry could be saved. The researcher interacted with the individual and convinced him of the way forward.

The employee admitted that he was sceptical and did not want change, but since there was communication with management and training of workers, he would "go with the flow." The comments suggest that a project such as this needs education, training, communication and management support.

Open communication is important in a project. The sharing of information between management and employees enhances the success of the project. It was mentioned that the dissemination of too much information and the interpretation of the information could cause problems within the work environment. The "grapevine" misinterprets information and employees become despondent. It was mentioned that 15 years ago operators were not allowed to speak and at present communication is encouraged in team-work.

An employee mentioned that "this was quite a change for them." It was mentioned that approximately 15 years ago the floor manager had an elevated office at a centralised point on the machine floor where there was a clear view of all employees. "Management by walk about" (MBWA) has become a prominent feature in the clothing industry. It was mentioned that the manager should be a part of the team on the production floor, know the employees by name and understand the problems experienced. Much could be achieved if team-work is implemented throughout the organisation and all employees strive to achieve the mission and vision of the organisation. Human assets need to be appreciated to enhance their motivational level. Working together could "change a mountain into a molehill," mentioned an employee.

It was mentioned that employees were often ignored and management made all the decisions. Issues such as product quality, customer expectations, productivity were never disclosed to employees. A motivated workforce can achieve labour efficiency without the pressure from management. It was explained that communication among the employees and management improved quality of production and an empowered employee could definitely add value to the organisation, no matter what problems were faced.

It was mentioned that customer focus and expectations, together with quality and on time delivery is an organisational problem, and not only the responsibility of the floor manager's. The team effort created a change in the working climate with information sharing that enables employees to better understand the operational aspects of an organisation.

The implementation process outcome elucidates that active employee participation with knowledge sharing could improve the performance of the organisation. Sharing information about the costs that go into production and the financial position of the organisation makes employees understand the importance of "right the first time, every time." With work-study officers involved in the process, all work measurement and method study evaluations were done with the team that shared ideas on methods and ergonomics. With the adoption of transparency in all activities employees understood their situation and that of the organisation.

\section{Benefits of the new system}

Encouraging results were achieved with a participative management style. On a general note, the sharing of information created a positive atmosphere. Due to the fact that this was a learning curve for the purposes of the research some of the benefits did not materialize. The multi-skilling of the employees helped overcome the effects of absenteeism. Employees, who normally sat at their machines for the entire day with one task, were now given the opportunity to teach and learn from others to resolve problems and become efficient team players. This was a challenging task.

The organisation benefited overall as the productivity of the line improved by $10 \%$, while labour efficiency improved by $15 \%$ and the morale of the employees improved with education, training, open communication and above all, being treated with dignity. Absenteeism had minimal effect on the cell, and employees going on a personal break were supported by the team.

The changing of jobs created better efficiency as operators became attuned to multi-tasking with a reduction in boredom as operators normally performed the same task for many years. It was, in a sense, a revival of energy that was experienced during the project.

It was mentioned that modular manufacturing produced the garment quicker, with no work in progress. There was an improvement in the visibility of tasks and operators, as there was minimal work in progress (approximately two units per operator). The team approach seemed to push the garments faster. It enabled operators to respond to customer requirements much quicker. Work in progress has reduced from a week to a day. People were taking responsibility for their processes as there were no rejects as the team ensured quality at each stage. Education and training improved that morale of the team with an improved output performance. Indirect labour was eliminated as members performed both 


\section{PICMET 2009 Proceedings, August 2-6, Portland, Oregon USA (C) 2009 PICMET}

direct and indirect operations. Supervision among team players was reduced as each member took ownership of the performance of the group.

\section{E. Complaints about the new system}

There were many challenges for the new system. Two employees complained and seemed to be negative about the system saying that they did not like moving around and were used to sitting in one place and working and did not like change. The concerns revolved around the following issues:

- multi-skilling, education and training;

- team-understanding and formation; and

- payment systems.

\section{Multi-skilling, education and training}

This was a drastic change from the norm as employees never experienced change for a decade and preferred remaining in a comfort zone. Therefore ongoing training on innovative business processes is imperative for an organisation. The concept of team-work (modular/cell manufacturing) was developed over 50 years ago, and operators were never exposed to it.

It was mentioned that in order for employees to accept change, there needs to be open communication among employees with the required education and training.

\section{Team understanding and formation}

The composition of the team is of the utmost importance. Members need to understand each other especially with regards to diversity. Therefore, team-members need to be thoroughly interviewed to determine whether they fit into teams. A series on education and training sessions are required to create an understanding of the dynamics of teamwork. Personality clashes should be avoided, and should there be a problem, it needs to be addressed immediately.

\section{Payment systems}

The rate of pay of machinists is a contentious issue. Employees were willing to go through the training but wanted a higher rate of pay. Team members felt that they were not rewarded for their input.

\section{DISCUSSION AND RECOMMENDATIONS}

The following discussion links the results from the case study in modular manufacturing in the South African clothing industry with some relevant literature and management experience:

\section{A. Leadership}

Change is initiated by leadership with strategic vision for the success of an organisation. The vision and mission comes from the organisation's leadership [21]. Visionary leadership drives the organisation towards the attainment of organisational objectives through the transfer of decision- making ability to the workforce. Thus the efficiency in the utilisation of resources is improved through the creation of trust.

Visionary leaders create and articulate a realistic, credible, and attractive vision of the future that grows out of and improves upon the present. Visionary leaders have three skills: ability to explain the vision, ability to express the vision, and ability to extend the vision. The leader needs to be proactive and use the current threat as an opportunity towards the creation of a competitive industry. The barriers in communication should be eliminated through the application of communication skills and the respect for others [7]. The sharing and learning in the workplace develops an increase in morale and the exposure of employee capabilities [20].

Leadership has the key to changing the organisation around through the effective implementation of fundamental methodology such as modular manufacturing that would improve the clothing and textile industry.

\section{B. Performance improvement strategy}

Performance management includes numerous methodologies. The focus in this situation is the implementation of fundamental productivity improvement initiatives. The recommendations for productivity improvement according to Rajesh et al (2003) are summarised as follows:

- The application of work-study principles. Work study and industrial engineering practices are important in labour intensive operations. Manufacturers tend to apply estimated time standards which are often incorrect. There is a crucial need to apply scientific work measurement and methods development methodologies. Manufacturers should move towards establishing a work-study department or alternatively train supervisors in the use of such tools.

- Apply training initiatives for all stakeholders. The productivity levels in the clothing industry indicate the need for training and development initiatives. Improvement initiatives would only be successful if supervision and management understood the concepts and implemented the changes. There is a vast range of education and training providers that are available for the delivery of clothing management related programmes. Organisations could sponsor staff to attend training programmes or conduct in-house training in both specialised and non-specialised skills. Thus scientific principles of line balancing, workflow layout, ergonomics and so forth could be implemented.

- Develop machinist training cells. Machinist training cells provide skills in the manipulation of fabrics, developed work ethics and create a learning curve for new employees towards the attainment of world-class performance.

- Develop quality management systems. The sample reported that the defect rate was approximately $3 \%$. A quality system would monitor and reduce the levels of 


\section{PICMET 2009 Proceedings, August 2-6, Portland, Oregon USA (C) 2009 PICMET}

defects which would save the organisations production costs.

- Technological improvement. Organisations need to upgrade their machinery at various stages in clothing manufacture. Computerised laying and cutting of fabric in the cutting room, automated sewing machines, and automated finishing are some of the areas of innovative machinery. Strategic investments should be made that would improve return on investment and productivity.

- Introduce productivity measurement systems. This would enable the recording of data at process points in real time, thus enabling effective decision making regarding the status of processes.

- Develop planning and scheduling of production. The aim of this would be the meeting of delivery dates as well as maximisation of resources. Organisations should look at software applications.

- Introduce incentive schemes. Productivity gains should be shared with the workforce in the form of incentives. This sharing would encourage labour efficiency and would assist in stimulating the morale of people.

- Black economic empowerment (BEE) initiatives. When management and workers are totally involved in the operation of the organisation and there is transparency of operation, the entire organisation takes ownership of profit/loss of the organisation.

- Style types. The fashion industry is overwhelmed by style changes. Style changes have both a positive and a negative connotation. On a positive note, industry is able to remain competitive by meeting fashion trends, while it causes frequent changes in set-up on the production line.

- When there is a change in the product style, the floor manager is involved with the adjustment of the production line to ease the flow between operations, machinists are required to adjust to new operations and machines require recalibration. This process causes a loss of time, thus increasing the cost of production.

- Production systems. There are three different production systems used in the clothing industry. They are modular manufacturing, the bundle system and the overhead conveyor system, predominantly known as the "Eton" system. The focus in the clothing industry is on the machining floor where garments are sewn.

Currently, virtually every manufacturer in SA clothing industry operates on the principle of the bundle system. The Bundle System (BS) is a system that uses bundles of cut components that are tied together in a bundle. These bundles travel from operator to operator until the garment is fully assembled. The operators' work station is specialised to handle the different types of sewing operations involved in the construction of the garment. The machinists specialise in the different operations to achieve labour efficiency. The Bundle System is as old as the clothing industry and organisations still practice this method of assembly around the world.

Self-directed teams are successful in many situations because the workers performing the functions are indeed in the best position to make the most effective changes to improve the process [9]. However, when self-directed teams were employed, the managers felt threatened because of the power given to the self-directed teams. Hence, the strained relationship between the self-directed team and the managers hampers the success of the project. In addition, if appropriate level of control is not exercised over a self-directed team, they may make decisions or perform functions not congruent with the overall goals and objectives of the organisation. It is recommended to start such as project as a trial run to understand the dynamics of teamwork [4] as also illustrated in the modular manufacturing case study.

\section{CONCLUSION}

Although not perfect, the team approach was perceived by most of the employees interviewed in this South African case study as being far superior to the traditional bundle system. This new management approach may not work for all companies, but for many it has proved feasible. Using the case study approach, this research provides insight about key components in the transition to a team system in the clothing industry. One of the keys to success in this plant was having upper level managers committed to the team system because it takes a great deal of time and financial resources in the beginning and it does not happen without careful planning. In addition, employees attributed the success of the transition to the plant manager. The manager not only harnessed the potential of the skills of the team, but empowered them to manage themselves. A successful organisation harnesses the potential of its workforce through open communication and the breakdown of barriers that prevent effective performance.

The philosophy of total management empowers all employees to manage their processes with a view to accomplish organisational mission and vision through education and training and the adoption of process improvement techniques of work-study, total quality management and so forth. A strategic management drive with the elimination of "silos" through commitment from the leadership could improve the status quo in the clothing industry.

\section{REFERENCES}

[1] Barnes, J., J.Aniruth and M.Morris.; "An analysis of the MIDP's contribution to the success of the South African automotive industry Policy lessons for the clothing, textile and paper and paper products industry," NPI Research Report. 2004.

[2] Basdeo,S. Clothing industry consultant. Kwa-Zulu Natal.2005-2008.

[3] Bell.T.; "Clothing chains wail over quotas is hypocrisy." SA Media. University of the Free State. The Star. 2006.

[4] Castro, W.A.S., R.C.Castro, S.I. Miron and P.U.A.Martinez,; "Modular manufacturing: an alternative to improve the competitiveness in the 


\section{PICMET 2009 Proceedings, August 2-6, Portland, Oregon USA @ 2009 PICMET}

clothing industry," International Journal of clothing science and technology,vol.16pp3. MCB University press, 2004.

[5] Chan, J.W.K. and N.D.Burns,; "Benchmarking manufacturing planning and control (MPC) systems: an empirical study of Hong Kong supply chains," Benchmarking: An International Journal, vol. 9,pp 256-277, 2002.

[6] Cooper, DR and P.Schindler,; Business Research Methods, McGrawHill, New York, 2006.

[7] Deming, W.E.; Quality, Productivity and Competitive Position, MIT Press, Cambridge, MA, 1982.

[8] Echikson,W.; "SA textile industry gets frayed by Chinese Imports," $S A$ Media. University of the Free State. Citizen. 8 September 2006.

[9] Evans, J. R.;Total Quality - management, organization and strategy, 4th edition, Thomson. New York, 2005.

[10] GEAR.; "Growth, employment and redistribution: A macroeconomic strategy," South African government, Pretoria, 1996.

[11] Gibbon, P.; "At the cutting edge: UK clothing retailers and global sourcing," Sub-series on Globalisation and Economic Restructuring in Africa. Copenhagen, working paper, 2002.

[12] Hill, T.; Operations Management: Strategic Context and Managerial Analysis, Macmillan Press, Basingstoke, 2000.

[13] Inggs, M.; "Clothing retailers seek an alternative to China," SA Media. University of the Free State, 17 January 2007.

[14] Krajewski, L.J., and L.P. Ritzman,; “Operations Management: Strategy and Analysis, 4th edition, Addison-Wesley, Reading, MA, 1996.

[15] Krige, M.; "New textile regulations welcomed," SA Media - The University of the Free State. Business Day, 12 February 2007.
[16] Makgalemele, T.; "The clothing industry is slow to react," SA mediaThe University of the Free State, Saturday Star, 16 September 2006.

[17] Palmi, R.; "A survey of South African Clothing companies in KwaZulu Natal," The Alexander Report, Durban, 2007.

[18] Paton, C and Bisseker, C.; "A stitch in time," Financial Mail, I-Net Bridge, 2005.

[19] Bheda R., A.S.Narag and M.L.Singla.; "Apparel Manufacturing: a strategy for productivity improvement," Journal of Fashion Marketing and Management, vol. 7 No.1 pp. 12-22, MCB Press, 2003.

[20] Robbins, SP and Decenzo, DA.; Fundamentals of management Essential concepts and applications, $5^{\text {th }}$ edition. Prentice Hall, New York, 2007.

[21] Stevenson, W. J.; Operations Management. 8th edition," Mcgraw Hill, New York, 2006.

[22] Ward, P.T., Durray, R.; "Manufacturing strategy in context: environment, competitive strategy and manufacturing strategy," Journal of Operations Management, vol 18.,No 2, pp123-38, 2000.

[23] WTO (2005), International Trade Statistics 2000, World Trade Organization, Geneva. http://www.wto.org.za

[24] Statistics South Africa, 2005. Various publications, including Survey of Employment and Earnings (SEE), Labour Force Survey and Retail Sales http://www.statssa.gov.za.

[25] Trade and Industrial Policy Strategies, 2005. Monthly trade statistics.http://www.tips.org.za.

[26] http://www.southafrica.info

[27] http://www.ilo.org.za 